\title{
O psiquiatra contemporâneo: transitando per via di porre e per via di levare
}

\author{
Carmem Keidann* \\ Flávio Shansis*
}

\begin{abstract}
Afirmar que o mundo atual cresceu em complexidade já é mais que um lugar-comum. As relações pessoais nessa sociedade multifacetada são muitas vezes difíceis não só de serem compreendidas mas também de serem vividas. O homem acaba por se tornar, ao mesmo tempo, ator em um roteiro dessa sociedade globalizada e mero espectador de uma peça a que ele tão-somente assiste. Resulta que esse homem do século XXI se sente fragmentado pelas múltiplas abordagens e vivências possíveis de um mesmo fenômeno. E como fica o psiquiatra dentro desse contexto?

Freud, valendo-se do que Leonardo da Vinci afirmara sobre as artes, teceu considerações a respeito de qual seria a proposta da psicanálise, contrastando-a com as terapias sugestivas. Estas últimas corresponderiam à per via di porre, que é o modo de operar a pintura, acrescentando partículas de cores em uma tela branca onde antes nada existia. Na escultura, por outro lado, processa-se a per via di levare, pois se retira do bloco bruto da pedra o que jaz oculto, e surge então uma obra que estava ali contida, método que, para Freud, correspondia à psicanálise ${ }^{1}$.
\end{abstract}

\footnotetext{
*Editores da Rev Psiquiatr RS
}

Valendo-nos das palavras de Freud e trazendo-as para uma outra situação, parece que a psiquiatria contemporânea - inserida em um contexto social multifacetado - necessita realizar essas duas vias. Ao mesmo tempo em que, ao atendermos um paciente, acrescentamos cores em uma "tela branca", a partir de diagnósticos cada vez mais sistematizados e confiáveis, também necessitamos, tanto para a tarefa diagnóstica quanto para a terapêutica, retirar do "bloco bruto" o que jaz oculto - o não dito -, para que tenhamos de fato uma compreensão o mais próxima possível da realidade, levando em conta não apenas a realidade externa, mas também o mundo interno do paciente. E é essa tarefa complexa e árdua que se impõe como nosso enorme desafio.

Já não se discute que as neurociências vieram a trazer à psiquiatria contemporânea um conhecimento amplo e fundamental para o entendimento das vias neuronais: a tela, antes branca, coloriu-se de muita informação. Também já não se discute que as descobertas de Freud e seus seguidores sobre o inconsciente alargaram o horizonte de percepção do ser humano de uma forma irreversível para a história da humanidade: o que jazia oculto em nosso bloco bruto desde 
então se torna visível. O desafio para o psiquiatra nos dias atuais é o de como transitar nessas duas vias sem dissociá-las, uma vez que elas somam conhecimento, e não excluem uma a outra. Como atender a esse homem de cérebro investigado em minúcias neuroquímicas, ao mesmo tempo que nos sabemos inseridos em um contexto transferencial e contratransferencial abordado de forma cada vez mais específica por diversas escolas e dentro de uma sociedade em que padrões de relacionamentos, de comportamentos e de identidade social se tornaram difusos e extremamente complexos?

Compreendemos que é exigido do psiquiatra contemporâneo esse entendimento mais amplo do homem atual. Talvez isso não seja possível sempre, e tenhamos que, muitas vezes, nos valer das subespecialidades, no mesmo sentido em que a sociedade caminha como um todo em seus inúmeros "nichos". Entretanto, sempre que possível, pensamos que um atendimento psiquiátrico deve ser pautado no bom conhecimento psicopatológico, na leitura de novas abordagens bioquímicas, na atualização psicofarmacológica permanente, no reconhecimento da realidade intrapsíquica e na aceitação de novas formas de interação social.

A Revista de Psiquiatria do Rio Grande do Sul pensa estar colaborando na formação desse perfil de psiquiatra e, a propósito, traz nesse número duas contribuições que bem simbolizam essa nossa postura. Na primeira, apresentamos aos leitores um editorial a convite que muito nos honra, escrito pelo Prof. Dr. Iván Izquierdo, um expoente pesquisador da ciência brasileira, reconhecido internacionalmente, e que nos brinda com um texto sobre a atualidade e a importância das descobertas de Freud, enfocando a questão da supressão e inibição das memórias e sua aplicação na clínica. A segunda é uma resenha do colega Maurício Marx e Silva sobre o livro Affect dysregulation and disorders of the self, de Allan Schore, psiquiatra e pesquisador das ciências biocomportamentais que tem registrado dados de integração entre as neurociênicas e a psicologia do desenvolvimento e a psicodinâmica.

Assim, sentimo-nos felizes em publicar um número consistente e com variada temática de artigos oriundos das mais diversas áreas da psiquiatria, propiciando uma visão integradora do indivíduo. Desta maneira, enfim, pretendemos contribuir com a formação do psiquiatra contemporâneo, auxiliando-o a transitar de forma mais segura tanto per via $d i$ porre quanto per via di levare quando do seu contato com os pacientes.

\section{REFERÊNCIA}

1. Freud S. (1905) Sobre a psicoterapia. In: Obras completas. Rio de Janeiro: S.E. Brasileira; 1969. vol. 7.

Copyright (C) Revista de Psiquiatria do Rio Grande do Sul - SPRS 